\title{
8 Framing Ambrose in the resources of the past: the late antique and early medieval sources for a Carolingian portrait of Ambrose
}

\section{Giorgia Vocino}

In 1964 Angelo Paredi, the prefect of the library of St Ambrose in Milan, published for the first time a long and unusual hagiographic account dedicated to the eminent doctor ecclesiae Ambrose (373-97). ${ }^{1}$ From then on, this text would be known under the name De vita et meritis sancti Ambrosii (BHL 377d in the Bollandist catalogue). So far, only one copy of the text has been discovered in a miscellaneous codex preserved at $\mathrm{St}$ Gallen (Stiftsbibliothek, 569). It contains saints' lives as well as fragments from heterogeneous texts such as the Apocolocyntosis by Seneca and the Apocalypsis of Pseudo-Methodius. ${ }^{2}$ The first codicological unit of the manuscript (pp. 3-97) is a libellus dated to the late ninth century: it consists of the entire text of this extraordinary Life of Ambrose, written in brown and black ink by a single hand in a plain, round and wellspaced Carolingian minuscule that Bernhard Bischoff defined as 'beste Mailänder Kalligraphie'. ${ }^{3}$

The De vita et meritis is a dense concoction of very different sources: biblical quotations can be found next to classical echoes that recall for instance pagan Roman authors like Virgil or Cicero. ${ }^{4}$ An analysis of the vocabulary suggests a ninth-century Carolingian background: as a matter of fact, the reference to the kingdom of Italy as the regnum italicum only features in charters and narrative sources from the reign of Louis the Pious (814-40) onwards. ${ }^{5}$ A late ninth-century date for the Milanese libellus, as integrated in St Gallen, Stiftsbibliothek, 569, confirms this

1 Paredi, Vita e meriti di S. Ambrogio.

2 Digital reproduction of the manuscript available at www.e-codices.unifr.ch/en/ description/csg/0569.

3 Bischoff, 'Italienische Handschriften', p. 178.

4 The wide range of sources signalled by Courcelle, Recherches sur saint Ambroise, pp. 143-8 has been further enriched by Tomea, 'Ambrogio e i suoi fratelli', 170-7, 191-5.

${ }^{5}$ Cf. Tomea, 'Ambrogio e i suoi fratelli', 156-9. 
timeline for the compilation: the De vita et meritis is an exceptional product of the second generation of the 'Carolingian Renaissance'.

Although extant in just one manuscript, the Carolingian Life of Ambrose was a considerable undertaking: its size and extreme learnedness made it unfit for liturgical reading - which might explain its lack of further dissemination, but the episcopal command (paterna iussio), as it is recalled by the anonymous compiler, ${ }^{6}$ reveals the interest of the highest ecclesiastical elites for the composition of a new Vita dedicated to the life and deeds of the Church Father and patron saint of Milan.

This chapter aims to reassess the compilation of this extraordinary hagiography in a wider Carolingian context. Following a short review of the historical background of Milan and its special bond with the Carolingian dynasty, this study will focus on the choices made by the anonymous hagiographer concerning both the sources he relied on for his narrative and the model of sanctity which he carefully shaped. In particular this contribution will analyse the use of the late antique Historia ecclesiastica tripartita (henceforth HT) in combination with Ambrose's political letters, as well as the integration of borrowings from the Lives of the most illustrious Frankish (Catholic) saints, St Martin of Tours and St Hilary of Poitiers. Along with this, the recurrent highlighting of Ambrose's parrhesia and zeal plainly shows the profound erudition of this Milanese compiler and his intention to offer a lively fresco of Ambrose's world. In doing so, he reveals his thorough understanding of the political and ecclesiastical debates in which the most learned Carolingian scholars engaged from the 830s onwards. The Life of Ambrose offered its commissioner (and recipient), the archbishop of Milan, the exemplum that enabled him to play a pivotal role on that heated arena.

\section{Betting on Ambrose alone: the valorisation of the cult of St Ambrose in Carolingian Milan}

In the aftermath of Charlemagne's takeover of the Lombard kingdom, a personal and sacred bond was established between the conqueror and the Milanese episcopate when, in 781, the Lombard archbishop Thomas (d. c. 783) baptised Gisela, Charlemagne's daughter, in the basilica of St Ambrose. ${ }^{7}$ Shortly hereafter, in 784, the Frankish archbishop Peter (c. 783-c. 803) founded a new monastery named after Ambrose, which he built in close proximity to the basilica where the saint was buried. ${ }^{8}$ A few years later the new foundation was granted a royal confirmation: the monks were now bound to pray for the well-being of the Carolingian

\footnotetext{
6 De vita et meritis, p. $51 . \quad 7 A R F$, s.a. 781, p. 56.

8 Preceptum: 789 October 23, Milano, ed. Natale, no. 30.
} 
family and the stability of the kingdom. ${ }^{9}$ After the doomed uprising of Bernard of Italy in 817 - who was backed by the Italian elites, among them the Milanese archbishop Anselmus ${ }^{10}$ - the strong bond with the Carolingians was renewed and strengthened with the appointments of the Frankish archbishops Angilbert I (822-3) and Angilbert II (82459), both well connected to Lothar I (818-55), who had been sent to Italy by his father, Emperor Louis the Pious, in $822 .{ }^{11}$

The long episcopate of Angilbert II is particularly well documented and his investment in the promotion of Ambrose's cult ranged from the liturgical to the artistic field. He was responsible for the elevation (exhaltatio as it is called in a contemporary Milanese manuscript) ${ }^{12}$ and relocation of the relics of Ambrose into a porphyry sarcophagus, which he had placed inside a new magnificent golden altar that can still be admired under the ciborium of the basilica ambrosiana to this day. ${ }^{13}$ The back of the altar was decorated with twelve vignettes that illustrate the life of Ambrose. ${ }^{14}$ Eleven episodes are taken from the late antique Vita Ambrosii (BHL 377), written by the Milanese deacon Paulinus in the early fifth century at the request of St Augustine, the bishop of Hippo (d. 430). ${ }^{15}$ A new episode had been added to celebrate the joining together of the Italian and Frankish kingdoms: it portrays St Ambrose at St Martin's deathbed, as recorded by Gregory of Tours in his De virtutibus sancti Martini. ${ }^{16}$ On one end of the altar, the patron saint of the Franks is again represented in symmetrical position to Ambrose's portrait, on the opposite end, in order to stress his equal status with the Milanese doctor.

Angilbert's successor, Archbishop Tado (860-8), also played an important role on the political and ecclesiastical Carolingian stage. In particular, he was remembered for his sapientia and for bestowing his patronage on learned Irishmen who came from north of the Alps. ${ }^{17}$ Moreover,

\footnotetext{
9 Preceptum: 790, April, Worms, ed. Natale, no. 31(=MGH Dip. Kar. I, n. 164).

${ }_{10} A R F$, a. 817 , pp. $147-8$.

11 On the revolt of Bernard and the Italian stay of Lothar I see Noble, 'The Revolt of King Bernard'; Jarnut, 'Kaiser Ludwig der Fromme'.

12 Milan, Archivio Capitolare della Basilica di Sant'Ambrogio, M 15, f. 140v.

13 Blaauw, 'Il culto di Sant'Ambrogio'; Cupperi, “"Regia purpureo marmore crusta tegit"'; for a complete study of the object see Capponi, L'Altare d'Oro.

14 Hahn, 'Narrative on the Golden Altar'.

15 Paulinus of Milan, Vita sancti Ambrosii, pp. 51-125.

16 Gregory of Tours, De virtutibus, p. 141.

17 The anonymous poet of one of the eight Italo-Carolingian poems gathered in Bern, Burgerbibliothek, 363 (third quarter of the ninth century) begs wise Tado to assemble the Irish scholars whom God placed in his charge (the poem is published among Sedulius Scottus, Carmina, pp. 236-7, vv. 23-4: Collige Scottigenas, speculator, collige sophos: / Te legat omnipotens; collige Scottigenas). On the Irish cultural influence in Carolingian Milan see Gavinelli, 'Irlandesi'.
} 
he had been appointed by the Italian emperor Louis II (844-75) to act as mediator between the excommunicated archbishops Gunther of Cologne and Theutgar of Trier, on the one hand, and the intransigent Pope Nicholas I (858-67) on the other, with regard to the intricate querelle about the divorce of Lothar II (855-69). ${ }^{18}$

Ambrose was the patron saint of Milan and a Father of the Church. However, of even greater value to the Milanese elites were his deeds and accomplishments vis-à-vis the imperial authority. In imitation of Ambrose ${ }^{19}$ the Milanese archbishops strove to assert their authority as the primates of the Italian kingdom and to establish their church as the official and righteous Carolingian lieu de mémoire in Italy: when Emperor Louis II died in 875 and his body was taken to Brescia, the Milanese archbishop Anspertus (868-81) hastened to claim the imperial remains and brought them back to Milan, where he had them buried in the basilica ambrosiana. $^{20}$

It is in this historical context that the De vita et meritis was composed: indeed, the hagiographer was working in one of the most prominent churches of the empire and a leading centre of learning.

\section{Framing the historical man: a Historia for a Vita}

The first remarkable choice of the anonymous compiler of the De vita et meritis concerns the profiling of the saint. Unlike Paulinus, who indulged in recounting the miracles performed by Ambrose as an exorcist and a thaumaturge, the Carolingian hagiographer is less interested in his wonder-working. Also, the valuable chronological frame offered by the late antique Vita Ambrosii is, surprisingly enough, just loosely followed: many episodes are abbreviated and some are even omitted entirely. The biography of the Milanese saint was also well documented thanks to the impressive harvest of texts produced by Ambrose himself, which was enriched further with material from one of his most renowned contemporaries, the doctor ecclesiae Augustine. Still unsatisfied with the material he found, the anonymous hagiographer of the De vita et meritis turned to 'universal histories', stating:

Although I would appear to want to add something to this grand total of sanctity and merits, I would rather take excerpts, especially because not only Paulinus,

${ }^{18}$ For a thorough analysis of the divorce case see Heidecker, The Divorce of Lothar II.

19 Angilbert II is openly represented acting like Ambrose in front of Emperors Lothar I and Louis the Pious in Andreas of Bergamo, Historia, p. 225.

${ }^{20}$ Andreas of Bergamo, Historia, p. 229. 
a man of remarkable memory, but also a great many other cosmographers sufficiently recounted many admirable deeds through which they demonstrated that, with doctrines as well as miracles, the provinces of the whole West were truly enlightened thanks to the holy grace glowing through him, who shines like the most luminous star among stars. ${ }^{21}$

His choice fell on the Latin translation of the three fifth-century chronicles written by the Greek church historians Socrates of Constantinople, Sozomen and Theodoret of Cyrus, the so-called Historia ecclesiastica tripartita (HT) prepared at Vivarium under the supervision of Cassiodorus. $^{22}$ The use of the $H T$ is unsurprising for two reasons: first, the Greek chroniclers had dealt precisely with the period of Ambrose's lifetime, whom they viewed as a hero of the Western Church. More importantly, the Carolingian period had developed a strong interest in history, Christian history in particular, which was characterised by a boost in the production of manuscripts containing late antique universal church histories. ${ }^{23}$ From the early ninth century onwards, in scriptoria throughout the Carolingian empire, the $H T$ was copied and disseminated while at the same time excerpts from this text started to pop up in the literary works of the most learned Carolingian scholars - among whom Jonas of Orléans, Frechulf of Lisieux, the Irishmen Dungal and Sedulius Scottus, Walahfrid Strabo, Hraban Maur and Hincmar of Rheims. ${ }^{24}$ In Italy, the $H T$ was above all promoted in the city of Milan, the former Lombard capital Pavia and the royal monastery of Bobbio. ${ }^{25}$

In this late antique universal history, Ambrose features as one of the leading churchmen of the Western empire in books VII, VIII and IX, from the time of the short-lived empire of Jovian (363-4) up to the death of Theodosius I (395). ${ }^{26}$ The Carolingian compiler of the De vita et meritis exploited every single paragraph dedicated to Ambrose, focusing

21 De vita et meritis, p. 51: Quamvis ad tantae sanctitatis et meritorum summam aliquid superaddere velle, potius decerpere videar, praesertim cum de ipso non solum Paulinus, insignis memoriae vir, sed et alii cosmograforum quam plurimi admiranda satis acta retulerint quibus velut praefulgidum sidus inter astra resplendens, totius Occidentis provincias, divina per eum radiante gratia, doctrinis pariter atque miraculis illustratas esse verissime comprobarunt.

22 For a more detailed presentation of the $H T$ and its context of writing see Désirée Scholten's contribution in this volume.

23 McKitterick, 'Texts, authority'; McKitterick, Perceptions of the Past, pp. 7-22.

24 For an overview of the medieval uses of the HT see Scholten, 'History of a Historia', pp. 129-32; especially on Frechulf see Ward in this volume; on the Carolingian borrowings of the 'penance of Theodosius' as recorded in the HT see Tomea, 'Ambrogio e i suoi fratelli', 182-3.

25 As shown by the manuscript tradition (cf. the monumental codex of the HT copied in the late ninth century in the region of Milan and now at Milan, Archivio Capitolare della Basilica di S. Ambrogio, M 7). Cf. Gavinelli, 'Il gallo di Ramperto', p. 422.

26 HT, pp. 374-579. 
on three key moments in particular: his election to the Milanese see after the episcopate of the Arian bishop Auxentius (HT VII, 8); the hostility of the imperial court and Empress Iustina's attempt to persecute Ambrose (HT IX, 20-1); and finally the rebuke and public penance Ambrose imposed on a misbehaving Theodosius I (HT IX, 30).

One can easily understand why the author extracted episodes that directly concerned the saint, but what is more baffling and therefore unexpected is the inclusion into a hagiographic account of what appears to be unrelated information. The compiler slipped in a digression on the brilliant solution of Valentinian I (364-75), amore captus, which allowed him to marry the beautiful virgin Iustina without repudiating his first wife, Severa, the mother of the Augustus Gratian (367-83). Thanks to the publication of a new law any man was authorised to have two lawful wives. ${ }^{27}$ This digression, at first sight pointless since it is unrelated to Ambrose's biography, gains significance if the compilation date is situated at the time of the querelle around Lothar II's divorce. It was the Milanese archbishop Tado (860-8) who had been appointed to find a middle ground between Pope Nicholas I and the king: the controversy referred to Lothar II's decision to repudiate his barren wife, Theutberga, and legitimise through wedding ties the union with his concubine Waldrada, who had already given him a son. Following Carolingian literary practices, an exemplum from the past is used to provide an authoritative frame of reference for present circumstances: whether a person or an episode from Roman classical literature, from the Bible or from late antique chronicles, its authority and exemplarity derived from being part of a past that had been written down and monumentalised - or canonised through the long selective processes by which traditions are established. ${ }^{28}$ Furthermore, the perfida Iustina had already proven to be the perfect typus to hint at contemporary controversial situations. Paschasius Radbertus, for example, had chosen the byname Iustina to refer to the (in his eyes) wicked Empress Judith. ${ }^{29}$ It should not come as a surprise therefore that, given the similar circumstances, the Milanese hagiographer incorporated in his narrative the successful ruse of Valentinian I - which had also been a troubling one as it had placed Ambrose's greatest opponent in

27 De vita et meritis, p. 61.

28 This line of thought, tightly connected to the study of cultural memory, has been fundamental for the development of the HERA project 'Cultural Memory and the Resources of the Past' and underlies all the contributions to this volume.

29 On Empress Judith see Ward, 'Caesar's wife'; on the use of the alias Iustina in Paschasius Radbertus' Epitaphium Arsenii, see de Jong, 'Becoming Jeremiah', pp. 186, 190; Ward, 'Agobard of Lyons', pp. 21-4. On the Carolingian tradition of by-naming see Garrison, 'The social world of Alcuin'. 
a position of power - either as a deliberate way to allude to Lothar II's divorce case or as an unpremeditated reflex of having been a witness of its extraordinary development.

The historical interest of the anonymous hagiographer is again manifest in his attention to the details of the imperial succession and his penchant for catchy episodes of late Roman history which inspired him to thicken his plot with additional information. Thus, he inserts in his Life of Ambrose, among other episodes, an account of the cunning trick used by the magister militum Andragathius, an emissary of the usurper Maximus (383-8), to take Gratian by surprise and kill him. ${ }^{30}$ The fight against usurpers is particularly stressed by the anonymous compiler: the rise in the Western empire of Eugenius, a doctor litterarum latinarum turned tyrant with the backing of the Frankish magister militum Arbogast, is recounted using excerpts from the $H T$. When Eugenius marched on Milan, Ambrose fled the city and went to Bologna. The hagiographer also added a personal note to the record: the saint fled Milan not because he was overwhelmed by fear, but because he was inflamed with divine zeal (divinae legis zelo succensus)! ${ }^{31}$ The highlighting of Ambrose's zeal, a leitmotiv in this text, will be analysed in more detail later in this chapter.

Indeed, the $H T$ was a treasure trove of information that could be plundered to complete Ambrose's portrait, as shaped by other documents. However, the Carolingian hagiographer was not exclusively interested in the details directly related to the saint. He contextualised Ambrose and added content to clarify each character's origins and motives, thereby making the 'world of Ambrose' a more coherent, integrated and detailed place as well as one strikingly similar to his present. ${ }^{32}$ Among the flighty fortunes of the empire, the only constant beacon in an otherwise shaken world is the bishop. It is easy to recognize there a reading key, written between the lines, for the Carolingian crisis and the struggles for the imperial legacy that followed the death of Emperor Louis the Pious in 840.

\section{Speaking with the saint's words. Ambrosian literature in the De vita et meritis}

Having framed the biography of Ambrose into a wider late Roman imperial background, Ambrose's deeds needed to be authoritatively explained

30 De vita et meritis, p. $75 . \quad{ }^{31}$ De vita et meritis, p. 91.

32 The 'world of Ambrose' was also the stage chosen by Paschasius Radbertus for his Epitaphium Arsenii: see de Jong, 'Becoming Jeremiah', p. 186 and de Jong, Epitaph for an Era. 
to the reader. The compiler is aided in his task by the numerous letters and sermons written by the Milanese doctor on different occasions. Among them are the letters collected in the tenth book of his epistolary, which is focused on political issues and enriches the palette of episodes in which Ambrose acted, and reacted, before the imperial authority. ${ }^{33}$ A corpus of letters concerning the conflict between the bishop and the Arian imperial court, facing one another in Milan, in particular caught the compiler's eye. The climax of this confrontation occurred in 385/6, when Valentinian II (375-92) ordered Ambrose to surrender a basilica to the Arians, a command the bishop refused to obey. Three letters were written in relation to this event: the first (Epistola 75) was addressed to Emperor Valentinian II; secondly, a sermon (contra Auxentium $=E p i$ stola 75a) postulated Ambrose's official statement on the matter, while a third letter to his sister Marcellina (Epistola 76) provided a summary of the events. These three texts aptly clarify Ambrose's position before the earthly rulers, that he summarised as follows: 'Tribute is Caesar's: it is not refused. A church is God's; it certainly ought not to be assigned to Caesar, because a temple of God cannot be under the jurisdiction of Caesar. ${ }^{34}$

This statement could easily be, mutatis mutandis, the flag of many ninth-century learned ecclesiastical scholars. Once again, the division between the juridical competences of the royal/imperial court and the Church occupied the limelight. Agobard of Lyon, Frechulf of Lisieux, Hincmar of Rheims and Sedulius Scottus referred back to Ambrose as one of the heroes of the ecclesia christiana, a strenuous defensor ecclesiae and an example of a righteous and authoritative way for a bishop to address a ruler. ${ }^{35}$

One of the most influential prelates of the Carolingian empire was Archbishop Hincmar of Rheims (845-82), a major supporter and advisor of King Charles the Bald and one of the few learned men who actually had many Ambrosian (and Pseudo-Ambrosian) works at his disposal. Hincmar also touched upon this point and used Ambrose's political letters the ones dedicated to his confrontation with the imperial authority on the Altar of Victory (Epistola 72), the synagogue of Callinicum (epist. 74), the

33 The tenth book and the epistulae extra collectionem are published in the third volume of the edition dedicated to Ambrose's letters and preceded by an exhaustive introduction focusing on the manuscript transmission (Epistulae et acta, vol. III).

34 Ambrose, Epistulae, p. 106: Tributum Caesaris est, non negatur, ecclesia Dei est, Caesari utique non debet addici, quia ius Caesaris esse non potest Dei templum (translation by Liebeschuetz, Ambrose of Milan, p. 159). Cf. De vita et meritis, p. 69.

35 Renswoude, 'Licence to speak', pp. 371-81. 
surrender of the basilica Portiana (Epistolae 75, 75a and 76) and the massacre of Thessalonica (Epistola 11 extra collectionem) - in his treatise De divortio Lotharii, written in 860 when the quarrel over Lothar II's divorce had reached its climax. ${ }^{36} \mathrm{He}$ relied on them once more in the occasion of the council of Douzy (871) and, later on, in his De fide Carolo regi servanda, written in $875 .{ }^{37}$ The extent of his quotations from Ambrose's letters shows that Hincmar had a manuscript collection that comprised not just the tenth book of Ambrose's correspondence, but also the letters extra collectionem, which he used in his De divortio. ${ }^{38}$ It is also particularly worth noting that in his De fide, Hincmar had combined almost the same selection of sources used by our Milanese hagiographer: paragraphs drawn from the funeral sermon for Theodosius are combined with letters $75,75 \mathrm{a}$ and 76 on the surrender of the basilica Portiana, as well as with extracts from the $H T$ (Book IX, 21, 23) and with sections from Paulinus' Vita Ambrosii - each document providing a clear example of how Ambrose stood before lay rulers. ${ }^{39}$ As Ambrose had done before him, Hincmar is especially concerned with clarifying and defining the different areas of intervention of rulers and bishops. In refusing to hand over the basilica Portiana, Ambrose had drawn a thick line demarking ecclesiastical and lay jurisdiction. Hincmar's use of Ambrosian literature thus shows to what extent the Milanese doctor had become a model and a reference in those edgy matters that were intensively debated in the second half of the ninth century. ${ }^{40}$

Thus, the choice of the compiler of the De vita et meritis to linger on the episode of the basilica Portiana cannot, and should not, be assessed by looking exclusively at the Milanese and Italian contexts. The selection of excerpts inserted into the hagiographic account demonstrates that the compiler was fully aware of the wider Carolingian debates that had been raging from the 830s onwards on the role and place of rulers and bishops in a Christian society. ${ }^{41}$

36 Hincmar, De divortio, pp. 148, 201-2, 245, 253-5. On Hincmar's involvement in the divorce case see again Heidecker, The Divorce of Lothar II, pp. 73-99.

37 Council of Douzy a.871, pp. 432, 488, 490, 500-2; Hincmar De fide, cols. 961-2, 964, 967-9, 981-3.

38 Among them the very rare epistle addressed to Theodosius I (Epistola 11 extra collectionem) about the 'Thessalonica massacre' (390), cf. Renswoude, 'Licence to speak', pp. $172-3$, particularly n. 136 . On the very limited circulation of the 'Thessalonica letter' see also ibid., p. 154, nn. 69 and 70.

${ }^{39}$ Hincmar, De fide, cols. 961-2, 964, 967-9, 973-5, 978-9, 981-3.

40 Morrison, 'Unum ex multis', pp. 680-2.

41 De Jong, 'The state of the church'; de Jong, 'Ecclesia and the early medieval polity'. 


\section{Humiliter, constanter atque prudenter: on the episcopal parrhesia as the right and successful model for dealing with earthly rulers}

Ambrose's opposition to secular authority proved to be obstinate and unwavering whenever the ecclesia Dei, which had been entrusted to his care, needed to be protected from attacks against its buildings, properties and rights, as well as its doctrinal foundations. The hagiographer is keen to stress this point and therefore interprets and presents the many instances in which Ambrose defined a righteous and appropriate defensio Ecclesiae performed by its good shepherd (bonus pastor).

The chief instrument at the bishop's disposal to correct and guide a misbehaving secular ruler was his parrhesia. Ambrose's way of addressing and rebuking an erring emperor owed to a long and prestigious tradition of 'free speech'. This practice, defined by a strict set of rhetorical rules, stemmed from classical judicial and political oratory and could be applied to both oral and written performances. Ambrose, who had been educated both in law and rhetoric, was a renowned master in this art. ${ }^{42}$ The hagiographer is particularly interested in fashioning the Milanese saint as a parrhesiast: his constantia is stressed owing to the many examples offered by the $H T$ and by the tenth book of Ambrose's letters. The entire vocabulary of parrhesia is present: increpare, admonere, fiducia, confidentia and constantia are the keywords of any discourse focused on the rhetorics of free speech and all of them, with the correlated derivative terms, are promoted and feature in the De vita et meritis. But the hagiographer did more than merely slavishly copy words from his sources. In fact, Ambrose's parrhesia is one of the major threads holding the narrative together: the constantia of the Milanese archbishop is stressed throughout the hagiographic account and the compiler is particularly inclined to indulge in the use of the adverb constanter and the superlative constantissimus when referring to the saint. Tellingly, together with constantia, two other virtues are associated with Ambrose, setting up a model for bishops. The hagiographer, for once speaking with his own words, openly recalls them when he states: 'with the continuous dispatch of writings, he [i.e. Ambrose] humbly, confidently and cautiously insisted and begged the emperor for the orders taken to be annulled'. ${ }^{43}$

The balance between humilitas, constantia and prudentia combined with patientia and sapientia is the recipe for Ambrose's achievements in this regard: the saint knows that humility and patience are the chief and guardian of virtues (magistra et custos virtutum humilitas atque patientia)

42 Renswoude, 'Licence to speak', on Ambrose, esp. pp. 137-74.

${ }^{43}$ De vita et meritis, p. 83: scriptis continuo missis, imperatorem humiliter constanter atque prudenter convenit ac supplicavit ut ea quae statuta fuerant rescinderentur. 
as he is also aware that his replies to, and against, the lay authority should be dressed with caution (prudenter occurrere). Owing to his ability to coordinate these moral qualities, Ambrose's speech could be received as an acceptissima oratio. ${ }^{4}$

The engine for the performance of these virtues could not be anything less than divine zeal (zelum divinae legis, according to the hagiographer). Deeds which could have appeared to be the result of fear before a tyrant are, on the contrary, the actions of a man inflamed by divine - and thus righteous - zeal. ${ }^{45}$ To provide a clear definition of the virtue of zelum, the hagiographer proceeds in two ways: first, he makes a clear distinction between zeal and anger (zelum and furor). Anger is a very pernicious state of mind which often led emperors to wrong actions: this was for example the case with Valentinian II, who, in reaction to Ambrose's refusal to hand over the basilica Portiana to the Arians, was inflamed with the greatest fury (furore maximo succensus), which made him issue very severe and unfair penalties against traders and commoners. ${ }^{46}$ Secondly, Ambrose's zeal allows the compiler to draw parallels between the saint and biblical prophets. Elijah and John the Baptist are compared to the Milanese bishop as they endured the plots of evil women like Jezebel and Herodias, while Ambrose had to deal with not two or three, but countless even crueller tyrants (non duos aut tres, sed innumeros tyrannos immo longe saeviores) whom he had justly admonished (corripuit), even though they repaid him with unjust persecution. ${ }^{47}$

The virtue of zelum and its dangerous counterpart, the vice furor, as well as Ambrose's parrhesia were particularly stressed in the works of one of the major scholars of the time, Sedulius Scottus. The chapters XII and XIII of his De rectoribus christianis were especially dedicated to the admonition and correction of the bishops and the corresponding zeal of the orthodox ruler. ${ }^{48}$ Again, the Milanese hagiographer appears fully aware of the contemporary debates on the appropriate relation between those men responsible for the ecclesia, and those responsible for the res publica. Sedulius was aware of the dangerous consequences of anger for a Christian king and thus presented zelum as one of the pillars on which Christian rule needed to be based. ${ }^{49}$ The compiler takes a similar attitude and depicts Ambrose as the ideal bishop who advises, admonishes and

44 Along with the oracle of a monk from the Thebaide and the omen of the apostles John and Philip, it is Ambrose's most accepted speech which led and supported Theodosius in his final battle against the usurper Eugenius (cf. De vita et meritis, p. 93)

45 De vita et meritis, p. 91: non timore coactus tyrannico, sed divinae legis zelo succensus.

46 De vita et meritis, p. $71 . \quad 47$ De vita et meritis, p. 119.

48 Sedulius Scottus, De rectoribus christianis, pp. 118-37.

49 Sedulius Scottus, De rectoribus christianis, pp. 128-37. On Sedulius' insistence on zelum and furor see Renswoude, 'Licence to speak', pp. 265-9; Staubach, Rex Christianus, II, pp. $153-4$. 
corrects the ruler, thereby successfully turning him into a perfect rector christianus, as had been the case for Theodosius.

\section{'Shining as the brightest star among stars': prestigious contemporary witnesses and hagiographic comparisons in the narrative of the De vita et meritis}

As the hagiographer stated at the beginning of his text, he intends to integrate into his narrative a record of the saint's deeds as they were remembered not only by his secretary, the deacon Paulinus, but also by others.

A contemporary witness and a renowned recipient of Ambrose's teaching was Augustine. The bishop of Hippo had often remembered and praised the Milanese bishop: his eloquence and doctrine (melliflua doctrina as it is defined by the Carolingian compiler) had played a fundamental role in Augustine's conversion to Catholicism. Augustine's memories are thus borrowed from the late antique Vita Augustini, written by his fellow-bishop and hagiographer Possidius and integrated into the De vita et meritis. It is in Milan that Augustine's adhesion to the Catholic faith started, 'gradually and little by little' (sensim atque paulatim), before eventually reaching full confirmation. ${ }^{50}$

The hagiographer then combines two other sources of information to complete his account of Augustine's Milanese stay, revealing once more the width of his culture and readings. Sections from Augustine's Confessiones are combined with a sentence from his letter CXLVII (epistola de videndo Deo) to the religiosa famula Dei Paulina. ${ }^{51}$ A potent image of the saint is created: Ambrose is presented as devoting himself to the infirmities of a crowd of busy men that prevent Augustine from speaking to him. ${ }^{52}$

A similar method is used to integrate two episodes from two early medieval hagiographies, of which the first reveals the compiler's familiarity with local Italian hagiographic literature and the second pays tribute to the overall Carolingian framework. In order to show Ambrose's prophetic spirit, the compiler added a paragraph from the Vita Gaudentii (BHL 3278), a text written in early eighth-century Novara, an episcopal town in the metropolitan diocese of Milan. It relates how the two saints met in Novara where they exchanged prophecies: while the Milanese

50 Possidius, Vita Augustini, p. 134. Cf. De vita et meritis, p. 79.

51 Augustine of Hippo, Confessionum, Book V, XIII.23, p. 70 and Book VI, III.3-4 and IV.6, pp. 75-7; Augustine of Hippo, Epistula CXLVII, p. 328.

${ }^{52}$ De vita et meritis, pp. $80-1$. 
doctor foretold the future episcopate of Gaudentius, the latter replied by clarifying that he would indeed become a bishop, but that he would be consecrated by someone else. The prophecy was confirmed when Gaudentius ended up being consecrated by Ambrose's successor, Simplician. ${ }^{53}$

Another prestigious contemporary saint, whose relations with Milan and its doctor ecclesiae were well known, was the patron saint of the Franks, St Martin of Tours. Thus, the compiler included an episode from Gregory of Tours' De virtutibus Martini, relating the dream of Ambrose, who, having fallen asleep over the altar, had been miraculously in spiritu deductum at St Martin's funeral. ${ }^{54}$ The insertion of a passage borrowed from the De virtutibus is openly signalled: 'although it is a digression, it does not seem to be incongruous to recall here from a compendium what happened at the death of the admirable bishop Martin of Tours'. ${ }^{55}$ The episode provided evidence for the equal status of the two saints something that was also celebrated on the Carolingian golden altar in the basilica of St Ambrose: as 'St Martin's wonders lit up the West, simili modo, Ambrose's flowers of eloquence and virtues perfumed all Europe and Africa'. ${ }^{56}$

At a first glance, borrowings from other hagiographic works would seem to be limited to these precise inclusions that are openly signalled by the hagiographer, but his use of hagiographic literature is much more pervasive and recurrent than that. For instance, his preface and closure are heavily influenced by a sermon attributed to Maximus of Turin (and occasionally to Ambrose himself), celebrating the dies natalis of St Eusebius, martyr and bishop of Vercelli. ${ }^{57}$ Also, the hyperbolic introduction of Ambrose 'shining as the brightest star among stars' and 'enlightening, with the divine grace beaming through him, the provinces of the West' is not our hagiographer's own work. ${ }^{58} \mathrm{He}$ is drawing from the Vita Gaudentii, adapting and merging it into the De vita et meritis. ${ }^{59}$ In turn, the hagiographer of the holy bishop of Novara had borrowed these images from Venantius Fortunatus' Vita Hilarii (BHL 3885). ${ }^{60}$ Even the account of the distress of Ambrose's ecclesia upon facing the pending death of its bishop - which is compared to a lost flock

53 De vita et meritis, pp. 100-3.

54 Gregory of Tours, De virtutibus, p. 591. Cf. De vita et meritis, p. 107.

55 De vita et meritis, p. 107: Non incongruum autem videtur hoc loco, licet extrinsecus, quod de admirabilis viri Martini Turonensis episcopi obitu gestum refertur, de compendio recordari.

56 De vita et meritis, p. 107.

57 De vita et meritis, pp. 50-1 and 120-1. Cf. Maximus of Turin, Sermones, pp. 24-6.

58 Maximus of Turin, Sermones, p. 51. $\quad 59$ Vita Gaudentii, p. 71.

60 Venantius Fortunatus, Vita Hilarii, p. 2. 
without a shepherd to defend it from wolves' bites - is borrowed from the Vita Gaudentii and rephrased to create a powerful image of the mourning Milanese church. ${ }^{61}$ Behind this scene there also shone an earlier layer: the same image was used in the late fourth century by Sulpicius Severus in his epistula ad Bassulam, which can be considered an appendix to his Vita Martini along with two other letters. ${ }^{62}$ The same goes for the final topos humilitatis of the Milanese compiler of the De vita et meritis, with which he underlined the insufficiency of a sterile mind and a poor style, unfit to praise the saint's virtues. The metaphor is also borrowed from the Vita Gaudentii whose hagiographer drew his inspiration from Paulinus of Périgueux's fifth-century De vita sancti Martini (BHL 5617). ${ }^{63}$

The De vita et meritis resembles a game of Chinese boxes, in which the Carolingian text draws from a pre-Carolingian document, which in turn uses late antique literature. But the ninth-century compiler was not fooled by the game: his cultural background allowed him to pick from whichever layer was most appropriate - pre-Carolingian or late antique as he shaped his own work. Thus he used, albeit without naming it, the Vita Hilarii by Venantius Fortunatus to borrow the beautiful image of the swimmer fighting against the waves in a sea of eloquence. ${ }^{64}$ When forced to choose between the accounts of Venantius and the anonymous hagiographer of the Vita Gaudentii, who both recounted how Ambrose's plea to die a martyr was frustrated only by the absence of an executioner, our hagiographer again preferred the former. ${ }^{65}$

The anonymous Milanese compiler was certainly familiar with the literature dedicated to the most prestigious champions of Catholicism, Saints Martin and Hilary, both of whom had well-known connections with Milan. Both men had stood up against Arianism, in particular against the Milanese bishop Auxentius, Ambrose's predecessor, and both had failed, resulting in their exile from Milan. Given the use of a dossier of texts dedicated to St Martin, it might be suggested that one of the so-called 'Martinelli élargis' was available in the Milanese scriptorium. This collection of documents dedicated to the patron saint of the Franks became particularly popular in the Carolingian period as a result of the impulse given by Alcuin, and later on by abbot Fridugisus (804-

\footnotetext{
61 De vita et meritis, p. 109. Cf. Vita Gaudentii, p. 82.

62 Sulpicius Severus, Epistula ad Bassulam, p. 338.

63 Paulinus of Périgueux, De vita Martini, p. 58.

64 Venantius Fortunatus, Vita Hilarii, p. 3.

65 De vita et meritis, p. 67; Tomea, 'Ambrogio e i suoi fratelli', 176.
} 
c. 834), to produce these hagiographic dossiers in the scriptorium of Tours. ${ }^{66}$

Despite the open reference to St Martin and the miraculous presence of Ambrose at his funeral, when it came to comparisons and panegyrics, borrowings are generally more discreet: it was not a matter of new episodes or witnesses, but the fashioning of the portrait of Ambrose that was at stake. The Milanese saint bore with the passions of human miseries, he endured the insults of his enemies, the complaints of the evil, the concern for the weak and the worry for those in danger, while his fame went beyond the limits of any conversation as it has exactly been said for St Martin in Sulpicius' letter to Aurelius. ${ }^{67}$ Furthermore, Ambrose had refused communion with both the Jews and the heretics as Hilary had done before him, and the Milanese saint's long list of virtues mirrors that of the bishop of Poitiers, as they are celebrated by Venantius. ${ }^{68} \mathrm{~A}$ comparison, somehow hidden between the lines, but easily detectable by the recipient of the text who - whether it was bishop Angilbert II or one of his successors, Tado (860-8) or Anspertus (868-81) - will undoubtedly have been a learned man familiar with Frankish literature and thus perfectly capable of decrypting and appreciating the allusions and comparisons with the most prestigious saints of the Western Catholic Church.

\section{Conclusions}

The Carolingian Life of Ambrose, the so-called De vita et meritis, sheds light on the cultural background of one of the major episcopal churches of the kingdom of Italy. Although the focus in the study of hagiography often tends to be on the local context, this multilayered document cannot be fully understood by just looking at its Milanese and Italian framework: the references to the overall Carolingian culture distinctively situate the De vita et meritis in the well-connected network of power and culture that shaped the empire reborn under Charlemagne.

The Milanese archbishops strove to impose their church as the lieu de mémoire of the Carolingian kings of Italy on account of the site's special relation to the Frankish sovereigns, following their conquest of the Lombard kingdom in 774 . Since then, scholars, scribes and manuscripts

66 On the ninth-century libelli dedicated to St Martin of Tours, see Hellmann, 'Die Auszeichnung der Textstruktur' as well as Bourgain and Heinzelmann, 'L'Euvre de Grégoire', pp. 300-9.

67 De vita et meritis, p. 105. Cf. Sulpicius Severus, Epistola ad Aurelium, p. 330.

68 Tomea, 'Ambrogio e i suoi fratelli', 175-7. 
had begun regularly to traverse the Alps, placing Milan in a key position in the Po valley. For example, paleographical evidence reveals repeated contacts with Corbie, the Bodensee area and the Rhineland ${ }^{69}$ Its geographical position together with the political and cultural connections established with the coming of the Carolingian kings played a fundamental role in re-establishing the importance of the Milanese church in the Italian kingdom.

With Milan's cultural network having greatly expanded, it comes as no surprise that the knowledge of a skilled and learned Milanese compilator was shaped by an extremely wide selection of readings ranging from local works, like the Vita Gaudentii, to Frankish ones, like the Vita Hilarii by Venantius Fortunatus or the dossier of hagiographies dedicated to $\mathrm{St}$ Martin. The intensive use of the $H T$ also should be assessed within the overall Carolingian framework: the early ninth century had witnessed a renewed impulse to produce and disseminate manuscripts containing this text, which in turn allowed the most learned men of the time to use it.

The Milanese compiler thus worked on a text that was much more than a hagiographic portrait of Ambrose: its references and comparisons - openly declared or subtly suggested - to biblical characters and prestigious fellow saints created a model for a proud and learned bishop who regarded himself as a central figure on the Carolingian political stage.

The De vita et meritis sets the biography of the ideal episcopus, an unyielding defensor ecclesiae more than a wonder-worker, whose task it was to protect his flock and his church against the dangers of heresy and the abuse or intervention of lay authorities in ecclesiastical matters. It is not a text meant for liturgical lecture, but a mirror and an edifying reading intended for a committed churchman whose office had placed him in the midst of very worldly affairs: a stage where skills and virtues such as constantia and zelum were highly valued instruments. Thus, the De vita et meritis presented the Milanese archbishops with a useful handbook: their role as mediators between the emperor and his kin, the popes and the local elites was never more pronounced than during the long reign of Emperor Louis II of Italy (840-75). After Louis' death, with the subsequent struggle for empire, this Carolingian frame started to creak. In a disintegrating political world, the model Ambrose provided lost its potency, and from the early tenth century the church of Milan started

${ }^{69}$ Especially since the bishopric of Chur had been part of the metropolitan jurisdiction of the Milanese church until the mid-ninth century. Cf. Ferrari, 'Manoscritti e cultura'. 
once again to look at the history of its episcopal origins. ${ }^{70}$ By then, the De vita et meritis had become useless and would have been condemned to oblivion, had not a monk of St Gall bound it together with other texts. Thus has been handed down to us the only witness of this learned and engaged Carolingian enterprise.

70 Tomea, Tradizione apostolica. 
